\title{
Temperature as indicator of optical properties and community structure of marine phytoplankton: implications for remote sensing
}

\author{
Heather A. Bouman ${ }^{1, *}$, Trevor Platt ${ }^{2}$, Shubha Sathyendranath ${ }^{3}$, William K. W. Li ${ }^{2}$, \\ Venetia Stuart ${ }^{3}$, Cesar Fuentes-Yaco ${ }^{3}$, Heidi Maass ${ }^{2}$, Edward P. W. Horne ${ }^{2}$, \\ Osvaldo Ulloa ${ }^{4}$, Vivian Lutz ${ }^{5}$, Margareth Kyewalyanga ${ }^{6}$
}

\footnotetext{
${ }^{1}$ Biology Department, and ${ }^{3}$ Department of Oceanography, Dalhousie University, Halifax, Nova Scotia B3H 4J1, Canada

${ }^{2}$ Biological Oceanography Division, Bedford Institute of Oceanography, Box 1006, Dartmouth, Nova Scotia B2A 4A2, Canada ${ }^{4}$ Universidad de Concepción, Casilla 160-C, Concepción 3, Chile

${ }^{5}$ Instituto Nacional de Investigacion y Desarrollo Pesquero, Paseo Victoria Ocampo 1, Mar del Plata, Argentina

${ }^{6}$ Institute of Marine Sciences, University of Dar-es-Salaam, PO Box 668, Zanzibar, Tanzania
}

\begin{abstract}
Using temperature as an independent variable, we were able to explain some 43 and $49 \%$ of the variance in the specific absorption coefficient of phytoplankton $\left(a^{*}(\lambda)\right)$ at wavelengths $(\lambda)$ 443 and $676 \mathrm{~nm}$, respectively, for some 1187 samples collected over a broad range of oceanographic regimes. Through examination of ancillary data, we demonstrate that our results are consistent with the view that the size structure and taxonomic composition of phytoplanktonic communities are regulated by physical processes, for which temperature is often a suitable proxy. Results obtained from multiple-linear regression analysis showed that by using temperature and chlorophyll a concentration, both of which can be retrieved by remote sensing, a larger proportion of the residual variance in $a^{*}(\lambda)$ could be explained than if chlorophyll a concentration were used alone. Furthermore, as a single independent variable, temperature could explain nearly an equal proportion of the variance of $a^{*}(\lambda)$ as chlorophyll $a$. These results show clearly the potential of using satellite-derived temperature data to improve retrieval of phytoplankton biomass from remotely sensed data on ocean colour.
\end{abstract}

KEY WORDS: Phytoplankton community structure $\cdot$ Absorption spectrum $\cdot$ Temperature $\cdot$ Remote sensing

Resale or republication not permitted without written consent of the publisher

\section{INTRODUCTION}

One of the main challenges in contemporary biological oceanography is understanding the factors that drive the regime shift in phytoplankton communities from picoplankton (prokaryotic)-dominated to diatom (eukaryotic)-dominated assemblages with a concomitant increase in the ratio of new production to total primary production (Legendre \& LeFevre 1989) and a decrease in the importance of the microbial loop (Longhurst 1998, Karl 1999). It is known that such transitions are often associated with a change from oligotrophic, stratified water columns to eutrophic, verti- cally mixed ones, with a corresponding increase in phytoplankton biomass (Margalef 1978, Cushing 1989, Cullen et al. 2002). Seasonal and regional changes in vertical stratification are usually accompanied by changes in water temperature and nutrient concentration.

The optical properties of the upper ocean contain latent information on the gross community structure in the pelagic ecosystem. Among these, the chlorophyllspecific absorption coefficient of phytoplankton $a^{*}(\lambda)$ (the absorption coefficient of phytoplankton at wavelength $\lambda$ divided by the chlorophyll a concentration) required for the interpretation of remotely sensed data on 
ocean colour is especially informative (Yentsch \& Phinney 1989, Bricaud \& Stramski 1990, Hoepffner \& Sathyendranath 1993, Lutz et al. 1996, Stuart et al. 1998, Sathyendranath et al. 1999). Variations in $a^{*}(\lambda)$ are related to changes in the size of the cells, to their taxon-specific pigment complement, and to the quantity of pigment per cell (Morel \& Bricaud 1981, Sathyendranath et al. 1987). Several studies have shown how $a^{*}(\lambda)$ varies according either to trophic status (Yentsch \& Phinney 1989, Bricaud et al. 1995, Lazarra et al. 1996) or to season (Sathyendranth et al. 1999). Such variations in the relationship between pigment concentration and phytoplankton absorption are known to lead to significant errors in the estimation of chlorophyll concentration from ocean-colour data (Carder et al. 1999, Sathyendranath et al. 2001). Therefore, an increased understanding of the sources of the variability in $a^{*}(\lambda)$ will lead to an improvement in the remote estimation of chlorophyll concentration using optical data.

Bricaud et al. (1995) examined the relationship between trophic status (as indexed by chlorophyll concentration) and chlorophyll-specific absorption using data collected from a variety of oceanic regimes. The rationale behind the selection of chlorophyll concentration as an indicator of phytoplankton community structure is based on the view that much of the variability in chlorophyll concentration is caused by fluctuations in the abundance of microphytoplankton (mainly diatoms) superimposed on a ubiquitous and more constant background of nano- and picoplankton biomass (Yentsch \& Phinney 1989). Yet, in temperate regions, diatoms may still be dominant at low chlorophyll concentrations, and small cyanobacteria have been observed at moderate $(1.25 \mathrm{mg} \mathrm{chl}$ $\mathrm{m}^{-3}$ ) chlorophyll concentrations (Morel 1997). Furthermore, in the context of improving chlorophyll-retrieval algorithms based on ocean-colour data, it is desirable to use an environmental predictor of $a^{*}(\lambda)$ that is independent of the reflectance signal, yet is accessible on the same synoptic scales. Sea-surface temperature is one variable that meets these criteria.

The dynamics of plankton communities are forced by the physical system in which they are embedded: temperature can be a useful indicator of the physicochemical properties of the marine environment, such as water-column stability and nutrient availability (Carder et al. 1999, Sathyendranath et al. 2001). The association of temperature with phytoplankton species-composition has been established since the birth of biological oceanography as a discipline (Gran \& Braarud 1935). More recently, Sosik \& Mitchell (1995) found a relationship between temperature and the absorptive characteristics of phytoplankton off the California coast.

In this work, we examine the relationship between $a^{*}(\lambda)$ and temperature based on optical and pigment data collected from oceanographic cruises covering a wide range of oceanic conditions. The roles of phytoplankton community structure, nutrient availability and water-column stability as potential factors influencing this relationship are examined and the results are assessed for their value in improving our understanding of what regulates phytoplankton community structure in marine systems and their implications for remote sensing of ocean colour.

\section{MATERIALS AND METHODS}

The field observations were made on a number of oceanographic cruises covering numerous oceanic regimes, from eutrophic upwelling regions to strongly stratified oligotrophic waters (Fig. 1). All samples were analysed by the Biological Oceanography Group of the Bedford Institute of Oceanography. For each station, measurements of temperature were made using a CTD (conductivity-temperature-density) profiler. Chlorophyll a concentrations were determined fluorometrically from pigment extracts before and after acidification using a Turner Designs fluorometer (HolmHansen et al. 1965). In addition, pigment composition was determined for most samples using reverse-phase, high-performance liquid chromatography analysis

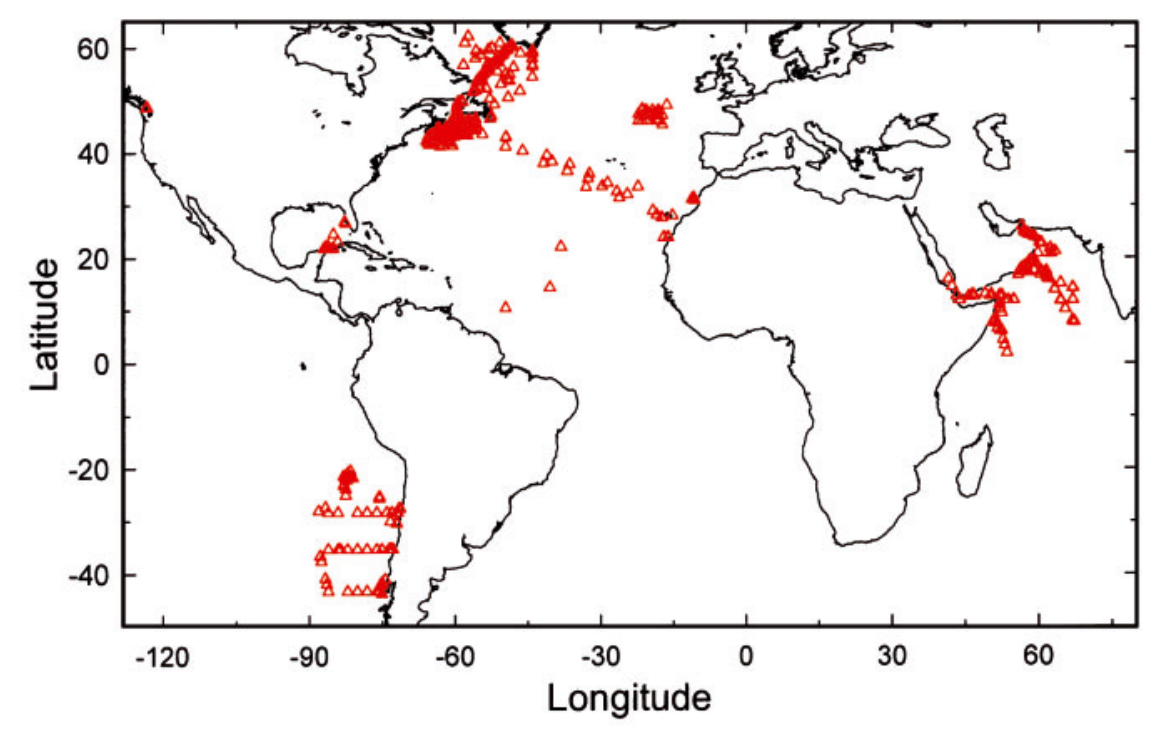

Fig. 1. Location of stations $(\Delta)$ where phytoplankton absorption, temperature and pigment concentrations were measured. Flow cytometric measurements were confined to Nova Scotian Shelf and Labrador Sea 
(HPLC) as described by Head \& Horne (1993). Ancillary data on the nitrate concentration were also available for the majority of stations sampled.

Absorption was measured using the filter technique. Briefly, between 0.5 and $1 \mathrm{l}$ of seawater was filtered through a $25 \mathrm{~mm}$ GF/F filter. The optical density of total particulates retained on the filter was measured using a Shimadzu UV-2101 spectrophotometer with a splitbeam, dual-detector optical system with an integrating sphere. To determine the spectral absorption by detrital material, pigments were extracted from the filter using the method of Hoepffner \& Sathyendranath $(1992,1993)$ for all samples analysed prior to October 1998 (extraction using DMSO/acetone); after this date, the method of Kishino et al. (1985) was used (extraction using methanol). Unpublished data (V. Stuart) showed no significant difference between these extraction methods. The extracted filters were scanned from 350 to $750 \mathrm{~nm}$ to measure the optical density of the detrital component.

Since the samples were collected over a wide range of trophic conditions, care had to be taken with the choice of the pathlength-amplification factor, which corrects for scattering by the filter. Moore et al. (1995) reported that significant errors might result if a conventional correction factor is applied to samples containing Prochlorococcus spp. To address this problem, we used the following formula (presented in Kyewalyanga et al. 1998):

$$
\begin{aligned}
O_{\mathrm{s}}(\lambda)= & F_{d v}\left\{A_{1} O_{p}(\lambda)+B_{1}\left[O_{p}(\lambda)\right]^{2}\right\}+ \\
& \left(1-F_{d v}\right)\left\{A_{2} O_{p}(\lambda)+B_{2}\left[O_{p}(\lambda)\right]^{2}\right\}
\end{aligned}
$$

where $O_{s}(\lambda)$ is the optical density of the particulate material in suspension at wavelength $\lambda_{i} 2$ sets of coefficients are applied to the contributions of Prochlorococcus spp. $\left(A_{1}\right.$ and $\left.B_{1}\right)$ and the rest of the phytoplankton population $\left(A_{2}\right.$ and $\left.B_{2}\right)$ to transform the total optical density measured on the filter $\left(O_{p}(\lambda)\right)$ to the optical density in suspension, based on $F_{d V}$ the ratio of divinyl chlorophyll $a$ to total chlorophyll $a$. The transformation (Mitchell \& Kiefer 1988)

$$
a(\lambda)=2.3 O_{s}(\lambda)(S / V)
$$

converts $O_{s}(\lambda)$ to absorption coefficients $a(\lambda)\left(\mathrm{m}^{-1}\right)$, where $S$ is the clearance area of the filter, $V$ is the volume of seawater filtered, and the constant 2.3 converts from base-10 logarithms to natural logarithms. For consistency, since HPLC pigment data were not available for all cruises, each absorption spectrum was normalised to Turner chlorophyll a concentration, to obtain the chlorophyll-specific absorption spectrum $a^{*}(\lambda)$.

The abundance and volume of picoplankton and nanoplankton cells ( 0.5 to $20 \mu \mathrm{m}$ ) were measured on some 8387 samples collected during 23 cruises to the Nova Scotian Shelf and the Labrador Sea (Li \& Harrison 2001), and covered 7 ecological provinces as defined by
Longhurst (1998). Chlorophyll autofluorescence was used to enumerate phytoplankton cells from samples collected at $10 \mathrm{~m}$ depth intervals throughout the photic zone using a FACSort (Becton Dickson) flow cytometer, as described in Li (1995). Estimates of cell biovolume and mean equivalent spherical diameter (ESD) for each sample were derived from measurements of cytometric forward-light scatter (Li 1995).

Satellite data from the SeaWiFS ocean-colour sensor were obtained from the Remote-Sensing Unit of the Bedford Institute of Oceanography for the period 8 April 1998 to 14 October 2000, corresponding to the dates of in situ sampling on the Nova Scotian Shelf. Chlorophyll a concentrations were determined by fluorometric analysis. Using SeaDAS software (Version 4.1), the satellite images were corrected for atmospheric influences using regional near-real-time meteorological and ozone data. Satellite-derived values of chlorophyll a were calculated using the standard OC4v4.1 algorithm (O'Reilly et al. 2000).

\section{RESULTS AND DISCUSSION}

The chlorophyll-specific absorption coefficent $a^{*}(\lambda)$ is a spectral property. The blue $(\lambda=443 \mathrm{~nm})$ and red $(\lambda=$ $676 \mathrm{~nm}$ ) wavelengths correspond to the 2 absorption peaks of chlorophyll $a$. We examined the relation between $a^{*}(\lambda)$ and temperature at 443 and $676 \mathrm{~nm}$ in some 1187 samples collected from various depths over a wide range of seasons and regions (Fig. 1). The measured chlorophyll concentrations ranged from 0.01 to $25 \mathrm{mg} \mathrm{chl}$ $\mathrm{m}^{-3}$ and the temperatures varied from -0.5 to $30^{\circ} \mathrm{C}$.

The plots reveal significant correlations between $a^{*}(\lambda)$ and temperature $(T)$ at $443 \mathrm{~nm}\left(a^{*}(443)=0.0138+\right.$ $\left.0.0049 T-0.00010 T^{2}, \mathrm{r}^{2}=0.43, \mathrm{p}<0.0001\right)$ and $676 \mathrm{~nm}$ $\left(a^{*}(676)=0.0081+0.0018 T-0.00010 T^{2}, \mathrm{r}^{2}=0.49, \mathrm{p}<\right.$ 0.0001) (Fig. 2). The cluster of points with low specific absorption coefficients at high temperature corresponds to 1 cruise conducted during the southwest monsoon in the Arabian Sea. When this cruise was removed from the analysis, some $58 \%$ of the variance in $a^{*}(443)$ $\left(a^{*}(443)=0.0171+0.0036 T-0.000022 T^{2}, \mathrm{r}^{2}=0.58, \mathrm{p}<\right.$ $0.0001)$ and $61 \%$ of the variance in $a^{*}(676)\left(a^{*}(676)=\right.$ $\left.0.0089+0.0015 T-0.000022 T^{2}, \mathrm{r}^{2}=0.61, \mathrm{p}<0.0001\right)$ could be explained by temperature alone.

When we try to account for the substantial fraction of the total variance in both $a^{*}(443)$ and $a^{*}(676)$ explained by temperature, 3 hypotheses present themselves. Temperature may be responsible directly for changes in optical properties, a covariate of temperature may be responsible, or the same physical processes that correspond to changes in ocean temperature, such as stratification of the water column, may also regulate phytoplankton community structure. 

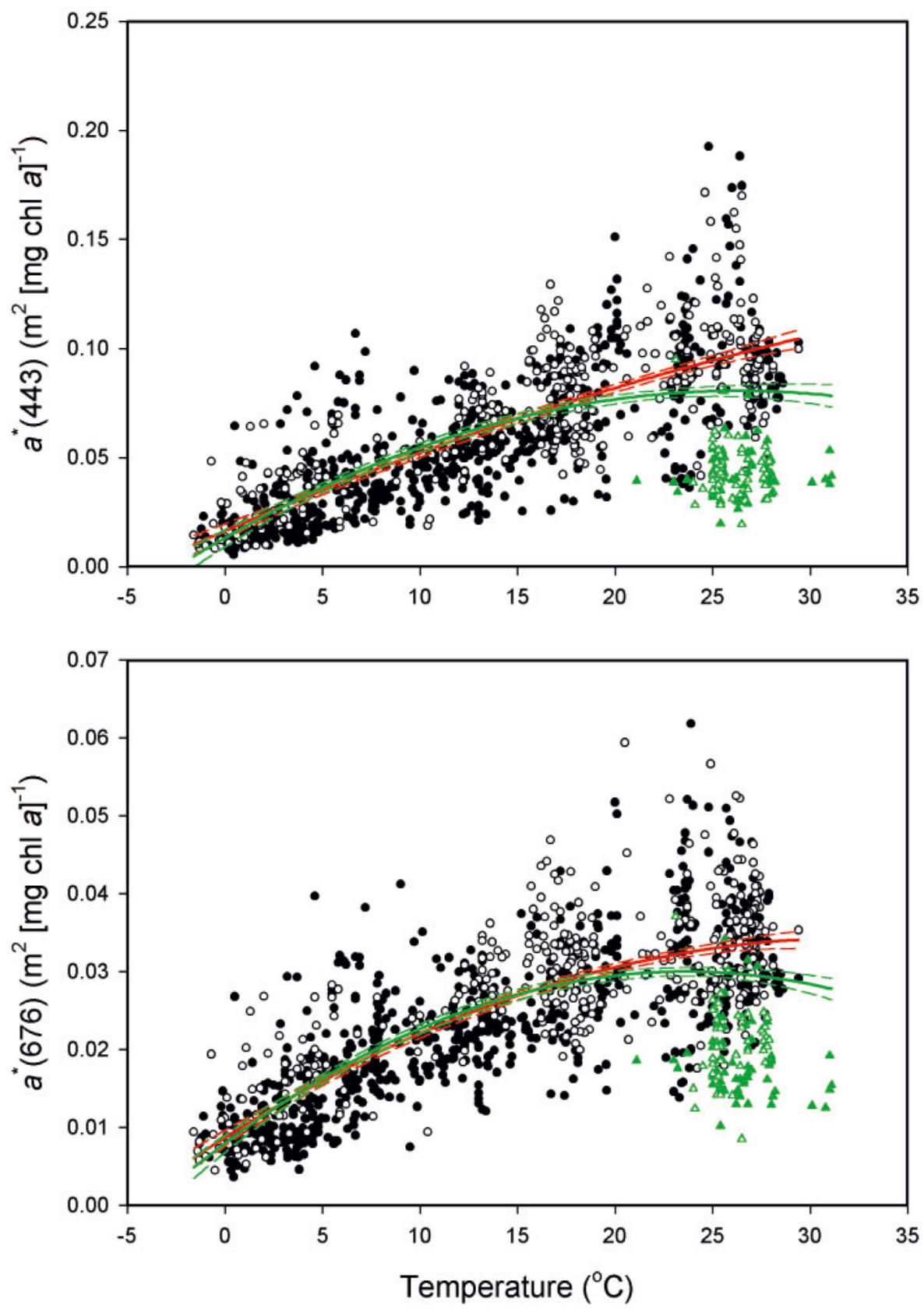

Fig. 2. Correlation between specific absorption coefficients at blue $\left(a^{*}(443)\right)$ and red $\left(a^{*}(676)\right)$ peaks of chlorophyll absorption and temperature $\left(T^{\circ} \mathrm{C}\right)$ for 1187 samples analysed. (•) Samples collected within top $20 \mathrm{~m}_{\text {; }}(\mathrm{O})$ samples collected at depths $>20 \mathrm{~m}$; green regression lines: second-order polynomial fits to entire dataset at 443 and $676 \mathrm{~nm}$; red line: polynomial fit to remaining dataset (•) for 443 and $676 \mathrm{~nm}$ after exclusion of data collected in Arabian Sea during the southwest monsoon (green triangles: filled $=<20 \mathrm{~m}$, open $=>20 \mathrm{~m}$ ); dashed lines: $95 \%$ confidence limits of equations

\section{Environmental factors causing variability in $a^{*}(\lambda)$}

Among the environmental properties known to modify the absorptive properties of phytoplankton cells are temperature itself, light history and nutrients, especially nitrogen. In several studies, the effects of these 3 factors on the specific absorption coefficient of phyto- plankton have been examined using phytoplankton cultures under controlled growth conditions.

In studies of the effect of temperature on Dunaliella tertiolecta and Thalassiosira pseudonana grown under light-saturating and nutrient-replete conditions (Sosik \& Mitchell 1994, Stramski et al. 2002), a response was observed directly counter to that shown in Fig. 2. Thus, 
a direct effect of temperature may therefore be ruled out.

Photoacclimation is another possible explanation for our results. Cells grown under high light intensities have lower intracellular pigment concentrations than those grown at low light (Falkowski \& LaRoche 1991), resulting in a corresponding increase in specific absorption (Geider \& Platt 1986). Given that our samples mostly represent conditions where density is dominated by temperature, we presume that stations sampled in different parts of the wide temperature range covered in this study represent different light regimes (surface irradiance, vertical mixing). In the range from (say) -2 to $5^{\circ} \mathrm{C}$, we would expect significant vertical mixing and low surface irradiance leading to low values of $a^{*}(443)$ and $a^{*}(676)$, whereas at temperatures greater than $12^{\circ} \mathrm{C}$ we would expect highly stratified conditions with high surface irradiance and high values of $a^{*}(443)$ and $a^{*}(676)$, as observed in our dataset (Fig. 2). However, if photoacclimatory change in intracellular pigment concentration was the only mechanism operating, we would also expect that surface samples would show higher values of $a^{*}(443)$ and $a^{*}(676)$ than deep samples, but this was not the case. In Fig. 2 the magnitudes of both $a^{*}(443)$ and $a^{*}(676)$ for surface and deep were similar, and there was no significant difference between the mean values of $a^{*}(443)$ and $a^{*}(676)$ for samples collected at the surface or at depth (Student's $t$-test, $95 \%$ confidence interval, p < 0.001). Thus, photoacclimation alone cannot explain the relationship between $a^{*}(\lambda)$ and temperature.

Changes in nutrient regime offer another potential basis for our results. In phytoplankton grown under steady-state nitrogen limitation (Sosik \& Mitchell 1991, Stramski et al. 2002), higher rates of nutrient supply led to lower $a^{*}(\lambda)$. To examine whether availability of nitrate might explain some of the variability in phytoplankton optical properties, both $a^{*}(443)$ and $a^{*}(676)$ were plotted against the corresponding ambient nitrate concentration for a subset of our data ( $\mathrm{N}=860$; Fig. 3) for which information on nitrate concentration was available. Again, the Arabian Sea showed anomalous results, with the some of the highest observed values of $a^{*}(443)$ and $a^{*}(676)$ occurring at nitrate concentrations in excess of $10 \mu \mathrm{M}$ (Fig. 3). The high degree of scatter in the relationship between ambient nitrate concentration and chlorophyll-specific absorption, especially at low levels of nitrate, is not surprising. Ambient nutrient concentrations are governed by both physical and biological mechanisms. Hence, during periods of rapid algal growth, such as the North Atlantic spring bloom, we would not expect the correlation between temperature and nitrate to be robust, since nitrate depletion would occur at a much faster rate than the vernal warming of the sea surface by solar heating. It can be argued that some indicator of nitrate supply would be a more suitable variable to approximate nutrient availability than ambient nitrate concentration. For example, Sosik \& Mitchell (1995) showed a strong relationship between $a^{*}(440)$ and the distance from the nitricline. Unfortunately, for most of the cruises examined in this study, our nutrient data were not sufficiently resolved in the vertical to establish a nitricline depth for testing this relationship.
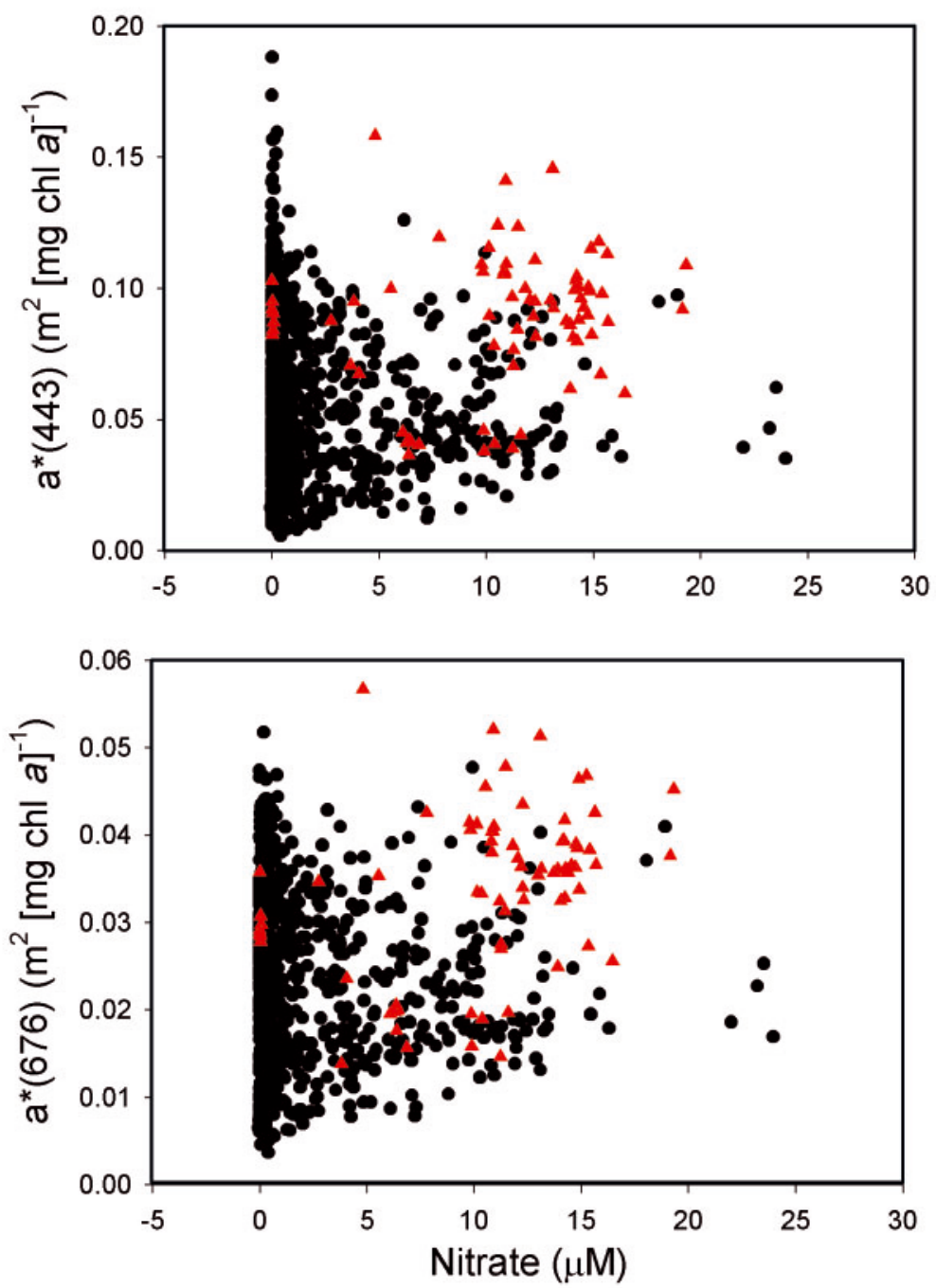

Fig. 3. Plots of $a^{*}(443)$ and $a^{*}(676)$ against nitrate concentration $(\mu \mathrm{M})$. Data are subset $(\mathrm{N}=860)$ of absorption samples presented in Fig. 2 since not all 1187 absorption measurements had corresponding nutrient observations. Red triangles: samples collected in Arabian Sea during June and July 1997 
Effect of phytoplankton community structure on $a^{*}(\lambda)$

Pigment markers allow us to classify algal samples according to the relative abundance of taxa present (Mackey et al. 1996) and, indirectly, give some indication of size composition (Claustre 1994). Cell counts, on the other hand, often do not cover the entire size spectra of phytoplankton. For example, conventional microscope counts often exclude cells in the picoplankton $(<2 \mu \mathrm{m})$ size range, whereas conventional flow cytometry measurements often exclude microphytoplankton $(>20 \mu \mathrm{m})$ due to the small sample volumes used for analysis (Li 2002). Conversely, provided HPLC pigment analysis is applied to samples retained by GF/F filters, the entire phytoplankton community will be included (Claustre 1994).

We used 19'-hexanoyloxyfucoxanthin as an indicator of prymnesiophytes, which generally fall into the nanoplankton (2 to $20 \mu \mathrm{m}$ ) size range (Jeffrey \& Vesk 1997), and zeaxanthin as an indicator of cyanobacteria (Synechococcus spp. and Prochlorococcus spp.), which typically fall in the picoplankton $(<2 \mu \mathrm{m})$ size range (Claustre 1994). Fucoxanthin is often considered to be an indicator of diatoms, which frequently fall into the microphytoplankton class $(>20 \mu \mathrm{m})$. However, fucoxanthin is also a dominant accessory pigment of prymnesiophytes (Jeffrey \& Vesk 1997). When the normalised pigment ratios were plotted against temperature, clear patterns emerged (Fig. 4a). In general, diatoms (as indicated by fucoxanthin) dominated mostly at low temperatures -2 to $2^{\circ} \mathrm{C}$. Prymnesiophytes coexisted with diatoms in the range from 2 to $10^{\circ} \mathrm{C}$. At temperatures between 10 and $18^{\circ} \mathrm{C}, 19^{\prime}$-hexanoyloxyfucoxanthin was the principal accessory pigment, indicating the prevalence of prymnesiophytes. The importance of picoplankton (as indicated by zeaxanthin) increased directly with increasing temperature.

Analysis of accessory pigments also allows us to explain the anomalous southwest monsoon cruise, for which $a^{*}(\lambda)$ values were low at high temperatures. During this cruise, intensive wind mixing did not change the sea temperature, yet the introduction of nutrient-rich water from depth produced blooms of diatoms (Sathyendranth et al. 1999), as indicated by high concentrations of fucoxanthin relative to chlorophyll $a$ at temperatures ranging from 20 to $29^{\circ} \mathrm{C}$.

Another way of looking at the change in taxonomic composition with temperature is to use a pigment index that reflects the fraction of large and small cells in a sample. We adopted the ratio $F_{p}$ proposed by Claustre (1994), which represents the ratio of diagnostic pigments associated with large cells (diatoms and dinoflagellates) to the sum of diagnostic pigments associated with both large and small cells. The ratio is calculated as follows:
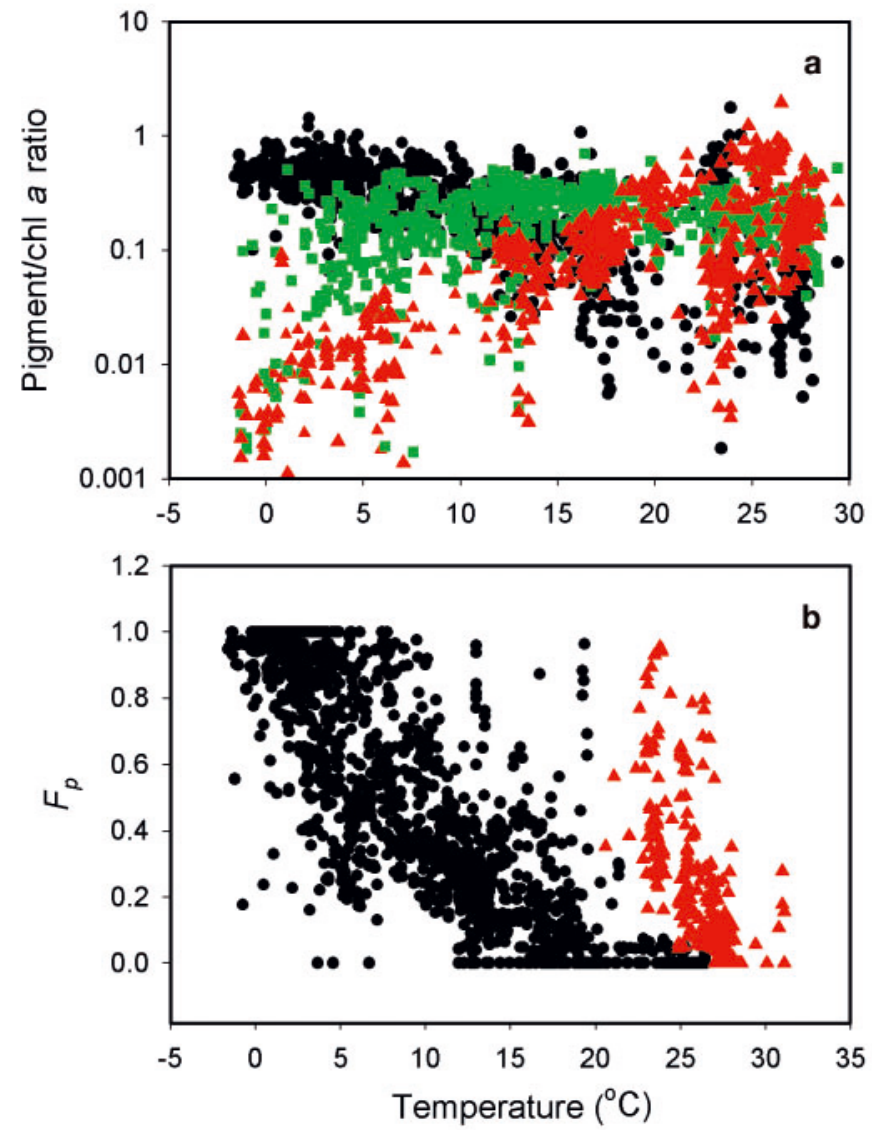

Fig. 4. (a) Relationship between concentration of 3 major accessory pigments relative to total chorophyll a (sum of chlorophyll $a$ and divinyl-chlorophyll a) and temperature. (•) relative concentrations of fucoxanthin, a conventional indicator of presence of diatom cells; green squares: relative concentrations of 19'-hexanoyloxyfucoxanthin, indicating presence of prymnesiophytes. The red triangles signify the relative zeaxanthin concentration, which indicates the presence of cyanobacteria. In samples for which the concentration of one of the pigment markers was below the limit of detection, the corresponding pigment ratio was not plotted. (b) Relationship between ratio $F_{p}$ (see Eq. 3) and temperature. Red triangles: data collected from Arabian Sea; $(\bullet)$ collected from remaining oceanic regimes

$F_{p}=($ fuco + per $) \times$

$\left(\text { fuco }+ \text { per }+19^{\prime}-\mathrm{HF}+19^{\prime}-\mathrm{BF}+\mathrm{zea}+\mathrm{chl} b+\text { allox }\right)^{-1}$

where fuco, per, 19'-HF, 19'-BF, zea, chl $b$ and allox represent the concentrations of fucoxanthin, peridinin, 19'-hexanoyloxyfucoxanthin, 19'-butanoyloxyfucoxanthin, zeaxanthin, chlorophyll $b$ and alloxanthin, respectively. The plot of the ratio $F_{p}$ against temperature (Fig. 4b) shows very clearly that the Arabian Sea falls into its own grouping. In the Arabian Sea dataset, ratios of $F_{p}$ varied between 0 and 1, with most points falling within a narrow temperature range between 24 and $30^{\circ} \mathrm{C}$. Thus, it would appear that in this particular region, temperature would be a poor predictor of 
phytoplankton community structure. For the remaining dataset, however, $F_{p}$ decreased gradually with increasing temperature. The ratio $F_{p}$ was also used to examine the relationship between taxonomic structure and phytoplankton optical properties. We plotted $a^{*}(443)$ and $a^{*}(676)$ against the $F_{p}$ for the entire dataset (Fig. 5), and found a strong negative relationship for both wavebands: $\mathrm{r}^{2}=0.49$ at $443 \mathrm{~nm}(\mathrm{p}<$ $0.0001)$ and $\mathrm{r}^{2}=0.43$ at $676 \mathrm{~nm}(\mathrm{p}<0.0001)$.

The relationship between the size structure of natural phytoplankton assemblages and temperature was also examined using flow cytometric data. The average equivalent spherical diameter $\left(<D_{s}>\right)$ of cells $<20 \mu \mathrm{m}$ in diameter for the top $100 \mathrm{~m}$ of the water column was computed for each of the 645 stations. The semi-log
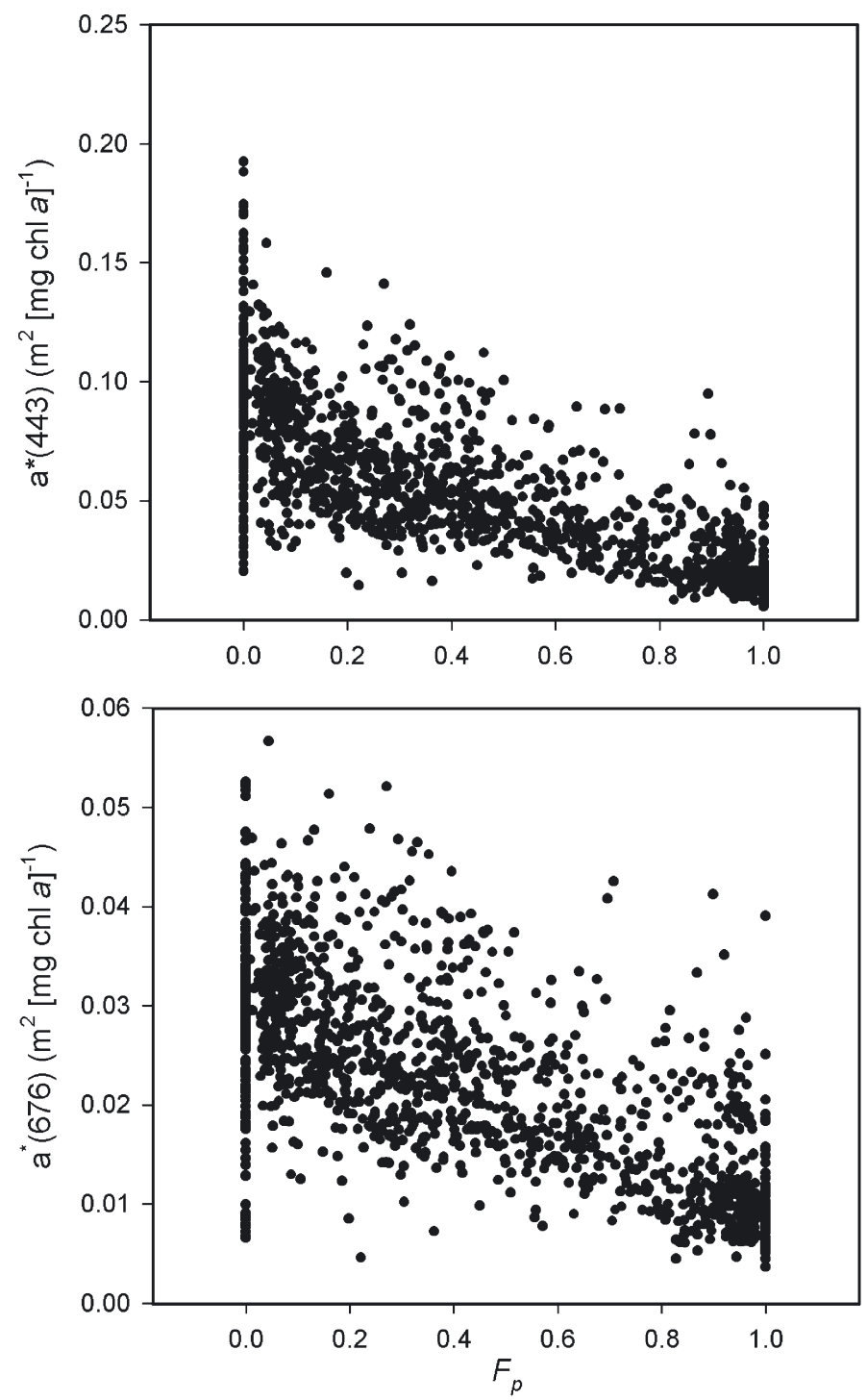

Fig. 5. Ratio $F_{p}$ versus chlorophyll-specific absorption coefficients at blue $(443 \mathrm{~nm})$ and red $(676 \mathrm{~nm})$ absorption maxima. (See Eq. 3 for calculation of $F_{p}$ )

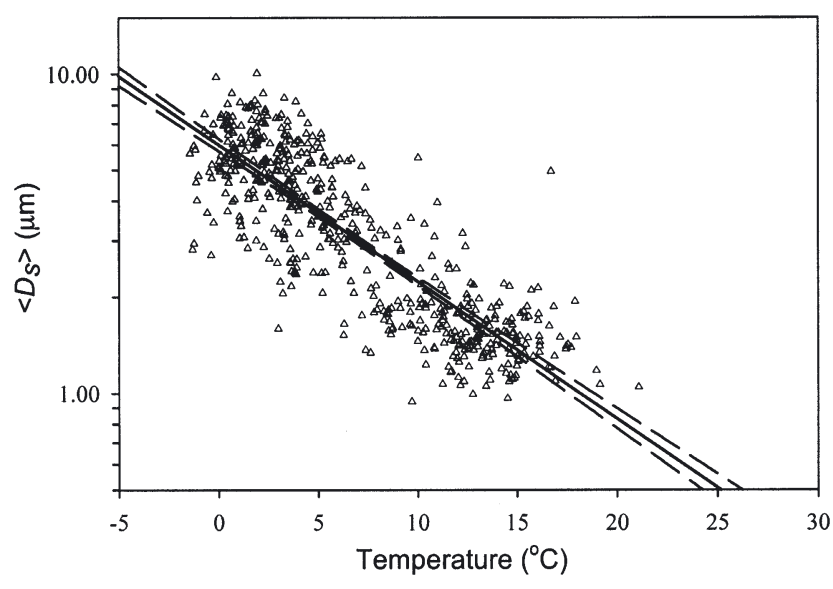

Fig. 6. Water-column average of mean equivalent spherical diameter $\left(\left\langle D_{s}\right\rangle\right)$ for nano- and picoplankton cells and temperature $(T)$ at $10 \mathrm{~m}$. Samples collected from 645 stations on the Nova Scotian Shelf and in the Labrador Sea. Continuous line: linear regression equation $\log \left\langle D_{s}\right\rangle=0.778-0.042 T\left(r^{2}=0.73\right)$; dashed line: $95 \%$ confidence limits

plot of $\left\langle D_{s}>\right.$ against the temperature at $10 \mathrm{~m}$ shows a clear linear pattern (Fig. 6).

The specific absorption coefficient of phytoplankton is sensitive to both cell size and pigment composition. The 2 peaks in phytoplankton absorption are associated with the wavebands of chlorophyll a absorption, one located at around $443 \mathrm{~nm}$ and the other at $676 \mathrm{~nm}$. Although pigment packaging affects the specific absorption coefficient in both wavebands, the influence of pigment composition on the absorption in the 2 wavebands differs markedly. Absorption in the $676 \mathrm{~nm}$ waveband is due primarily to chlorophyll $a$, although the contribution of chlorophyll $b$ can be important in samples containing low-light acclimated Prochlorococcus spp. cells. However, in the $443 \mathrm{~nm}$ waveband, the influence of accessory pigments, especially photoprotective carotenoids, can be significant. Based on a study of 6 species of phytoplankton cultures grown under a range of irradiance levels, Fujiki \& Taguchi (2002) reported that under high light conditions the influence of photoprotective pigments weakened the relationship between cell size and specific absorption at $440 \mathrm{~nm}$, whereas under low light conditions the relationship between $a^{*}(440)$ and cell size was significant. In the red region of the visible spectrum, the relationship between cell size and $a^{*}(\lambda)$ was significant at all growth irradiances. Based on their observations, it would appear that the absorptive characteristics of phytoplankton in surface waters, which are detected by the satellite optical sensors, may be related more strongly to photoprotective pigment composition than to cell size. Yet, in the present study, a strong relationship was observed between the absorptive properties 
in both the blue and red regions of the spectrum and phytoplankton size structure. The reason for this strong correlation between specific absorption at the 443 and $676 \mathrm{~nm}$ wavebands and cell size is a relative increase in the concentration of photoprotective pigments moving from diatom-dominated waters to cyanobacteria-dominated waters. Zeaxanthin, a photoprotective carotenoid that is a chemotaxonomic indicator of the cyanobacteria Synecoccocus spp. and Prochlorococcus spp., is a dominant accessory pigment in oligotrophic tropical and subtropical waters. In surface waters, this pigment contributes up to approximately half of the total absorption at $440 \mathrm{~nm}$ (Babin et al. 1996, Bouman et al. 2000). It is therefore fortuitous that picoplanktonic cells exhibit both lower pigment packaging and higher relative concentrations of photoprotective pigments than larger cells, allowing the sizedependent change in chlorophyll-specific absorption to be similar at both wavebands.

The results of 2 independent analyses (HPLC and flow cytometry) thus provide strong support for the view that broad changes in community structure of phytoplankton in the global ocean, as indexed by pigment composition and size composition, are associated with the distribution of temperature. Moreover, cell size is an important determinant of the optical properties of phytoplankton. We believe that these factors offer the most plausible explanation for the robust relation between $a^{*}(\lambda)$ and temperature.

The principal result may be presented in another way. The general increase in absorption by phytoplankton with increasing concentration of chlorophyll is well known (Prieur \& Sathyendranath 1981, Sathyendranath \& Platt 1988). Indeed, it provides the basis for the remote sensing of phytoplankton biomass (Morel \& Prieur 1977, Gordon \& Morel 1983). When phytoplankton absorption at $676 \mathrm{~nm}$ is plotted against chlorophyll concentration and then partitioned according to temperature (Fig. 7a), the significance of temperature, and therefore of community structure as a modulator of bio-optical characteristics, becomes very clear.

\section{Implications of results to remote sensing of ocean colour}

Can these results be exploited to improve the synoptic census of phytoplankton by ocean-colour remote sensing? They certainly can. Chlorophyll retrieval by remote sensing depends on the reflectance at certain wavelengths in the visible part of the spectrum (Gordon \& Morel 1983). Reflectance is a function of absorption (Gordon \& Morel 1983). Cell size (Duysens 1956) and pigment complement (Bidigare et al. 1990, Hoepffner \& Sathyendranath 1991, 1993), both of which we have shown to be significantly correlated with temperature,
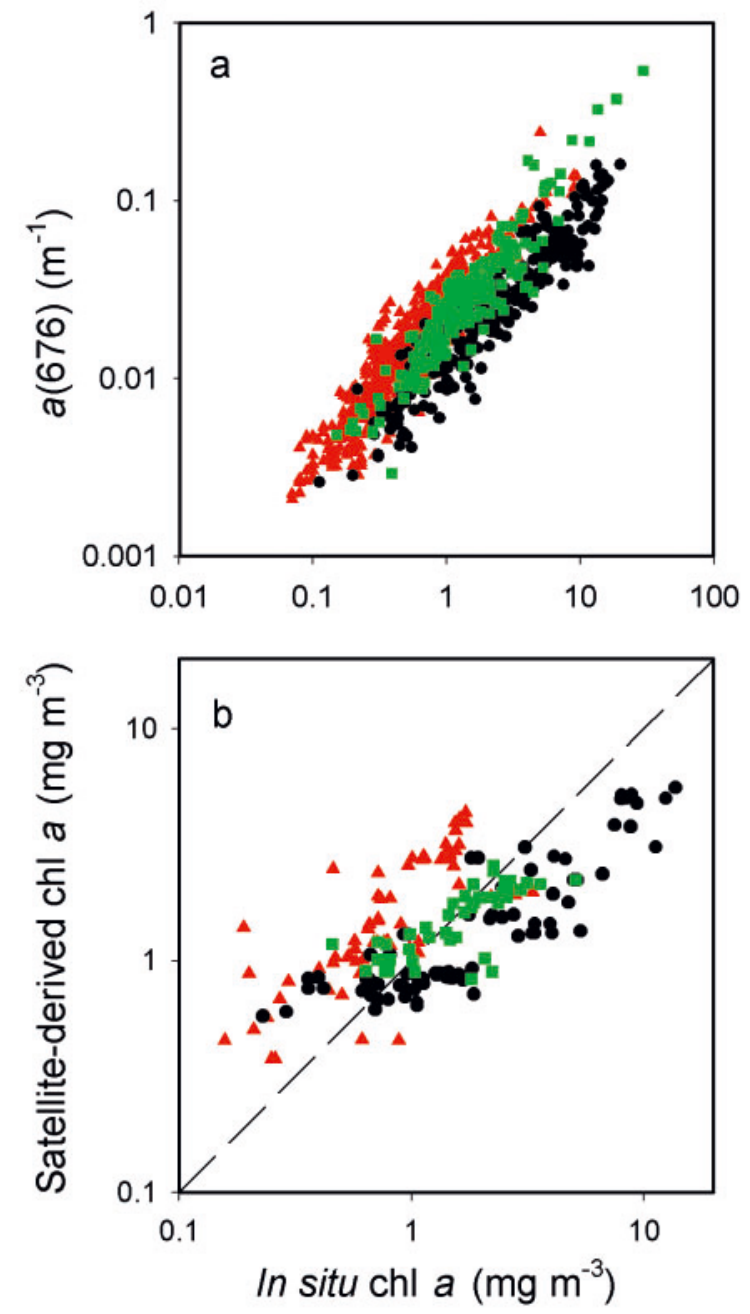

Fig. 7. (a) Log plot of absorption coefficient of phytoplankton at $676 \mathrm{~nm}$ a(676) $\left(\mathrm{m}^{-1}\right)$ and in situ chlorophyll a concentration. (•) samples collected at temperatures $<5^{\circ} \mathrm{C}_{\text {; }}$ green squares: samples collected at temperatures of 5 to $12^{\circ} \mathrm{C}_{i}$ red triangles: samples collected at temperatures $>12^{\circ} \mathrm{C}$. Total number of observations $=1187$. (b) Log plot of satellite-derived chlorophyll a concentration (using SeaWiFS OC4 algorithm) against corresponding in situ chlorophyll a concentration for samples collected from the Nova Scotian Shelf $(\mathrm{N}=192)$. Black circles, green squares, red triangles: data at temperatures $<5^{\circ} \mathrm{C}$, 5 to $12^{\circ} \mathrm{C}$ and $>12^{\circ} \mathrm{C}$, respectively

are known to influence the magnitude and shape of $a^{*}(\lambda)$. We have established that residual variance about the regression of chlorophyll-specific absorption on chlorophyll concentration is reduced significantly for all SeaWiFS wavebands when temperature is included as an independent variable (Table 1). The low $\mathrm{r}^{2}$ values for regressions of chlorophyll and temperature against $a^{*}(555)$ are due to the minimal amount of variability in specific absorption caused by accessory pigment absorption and pigment packaging in this region of the spectrum. Both the $r^{2}$ values and regression coefficients show strong wavelength dependence, similar to the 
Table 1. Linear regressions of log-transformed chlorophyll-specific absorption coefficient $\log _{10}\left(a^{*}(\lambda)\right)$ against log-transformed chlorophyll $a$ concentration $\log _{10}(C)$ and temperature $T$, and multiple linear regression of $\log _{10}\left(a^{*}(\lambda)\right)$ on both $\log _{10}(C)$ and temperature $(T)$. Coefficients of equations $\log _{10}\left(a^{*}(\lambda)\right)=b \log _{10}(C)+d_{i} \log _{10}\left(a^{*}(\lambda)\right)=b T+d$ and $\log _{10}\left(a^{*}(\lambda)\right)=b \log _{10}(C)+e T+d$ and their corresponding $\mathrm{r}^{2}$ values are presented for the 6 SeaWiFS wavebands in the visible spectrum. Number of observations in each case $=1187$. (It has been shown [Sathyendranath \& Platt 1988] that linear equations fitted to log-transformed phytoplankton chlorophyll-specific absorption coefficient against log-transformed chlorophyll concentration have some limitations, especially at very low chlorophyll concentrations. However, linear models of log-transformed variables are used in this analysis to accommodate the additional independent variable temperature)

\begin{tabular}{|c|c|c|c|c|c|c|c|c|c|c|}
\hline \multirow[t]{2}{*}{$\lambda$} & \multicolumn{3}{|c|}{$\log _{10}\left(a^{*}(\lambda)\right)=b \log _{10}(C)+d$} & \multicolumn{3}{|c|}{$\log _{10}\left(a^{*}(\lambda)\right)=b T+d$} & \multicolumn{4}{|c|}{$\log _{10}\left(a^{*}(\lambda)\right)=b \log _{10}(C)+e T+d$} \\
\hline & $b$ & $d$ & $r^{2}$ & $b$ & $d$ & $r^{2}$ & $b$ & $d$ & $e$ & $\mathrm{r}^{2}$ \\
\hline 412 & -0.332 & -1.404 & 0.49 & 0.017 & -1.624 & 0.42 & -0.235 & -1.538 & 0.010 & 0.58 \\
\hline 443 & -0.397 & -1.346 & 0.54 & 0.021 & -1.609 & 0.46 & -0.280 & -1.506 & 0.012 & 0.65 \\
\hline 490 & -0.424 & -1.554 & 0.56 & 0.021 & -1.817 & 0.42 & -0.317 & -1.702 & 0.011 & 0.64 \\
\hline 510 & -0.346 & -1.745 & 0.48 & 0.017 & -1.966 & 0.39 & -0.252 & -1.873 & 0.009 & 0.56 \\
\hline 555 & -0.162 & -2.176 & 0.12 & 0.010 & -2.309 & 0.14 & 0.090 & -2.276 & 0.007 & 0.17 \\
\hline 670 & -0.275 & -1.735 & 0.43 & 0.016 & -1.945 & 0.47 & -0.166 & -1.885 & 0.011 & 0.58 \\
\hline
\end{tabular}

findings of Bricaud et al. (1995). Also important is that the predictive ability of temperature as a single independent variable is nearly equal to that of chlorophyll for all the SeaWiFS wavebands. More directly, we examined the regression of the remotely sensed estimate of chlorophyll (NASA OC4 V4.1 algorithm; O'Reilly et al. 2000) against chlorophyll measured on some 192 samples collected by ship from the Nova Scotian Shelf. In the ideal case, this regression should have a unit slope. We found that the samples separate distinctly into groups, depending on the temperature regime from which they were taken (Fig. 7b). Thus, sea-surface temperature can be used to select chlorophyll-retrieval algorithms to account for changes in the optical characteristics of phytoplankton caused by changes in phytoplankton community structure; this reduces potential errors in the estimation of sea-surface chlorophyll (see also Carder et al. 1999).

\section{Temperature as index of environmental conditions}

Although it is not surprising that both the size and taxonomic composition of phytoplankton cells govern most of the variability in $a^{*}(\lambda)$, we also need to understand why temperature is such an effective indicator of phytoplankton community structure for such a diverse group of oceanic provinces. Yentsch \& Phinney (1989) proposed that variability in the chlorophyll-normalised absorptive properties of phytoplankton is caused by changes in the availability of new nitrogen. Watercolumn stability is known to influence both nitrogen availability and temperature within the photic zone. The transport of cold, nutrient-rich water to the surface layers is one of the major sources of new production in the open ocean. It is this link between temperature and new nitrogen supply that has been exploited to esti- mate new production from surface temperature fields obtained by satellite (Sathyendranath et al. 1991).

Apart from its role in supplying nutrients from depth to well-lit surface layers, vertical mixing will also favour the presence of larger cells by allowing them to remain suspended within the photic zone. Species succession in phytoplankton communities has been attributed to changes in the physical environment, namely advection and turbulence (Margalef 1978, Cullen et al. 2002). A recent study by Rodriguez et al. (2001) showed that mesoscale vertical motion was important in regulating the size structure of marine phytoplankton. However, it is important to point out that the relationship between temperature and vertical stability is not always a robust one. For example, in coastal and polar regions, salinity can play a dominant role in controlling water-column stability, varying as a function of terrestrial runoff and ice melt, respectively. We have also seen, in the case of the Arabian Sea, that high levels of vertical mixing can result in negligible changes in sea-surface temperature.

The limited value of temperature as an indicator of turbulence in the Arabian Sea region may explain the poor correlation found there between temperature and phytoplankton community structure. Another potential cause for the poor relationship is that biotic rather than abiotic factors may play an important role in regulating phytoplankton community structure in this region. Results from a study by Goericke (2002) in the monsoonal Arabian Sea suggest that phytoplankton community structure is primarily regulated by zooplankton grazing rather than prevailing physical and chemical conditions. Thus, in regions such as the Arabian Sea, where top-down control of phytoplankton community structure exists, alternative remote-sensing algorithms of seasonal changes in community structure may be necessary. 
The regions examined in this study generally fall into 2 turbulence-nutrient regimes: low turbulence and low nutrients, which in general are associated with high temperatures; and high turbulence and high nutrients, which are generally associated with low temperatures. However, there are 2 other regimes of turbulence and nutrient availability not represented in this study (Margalef et al. 1979, Cullen et al. 2002).

The first regime is low turbulence and high nutrient conditions in coastal regions. In this regime, there are 2 mechanisms by which low-turbulence-high-nutrient conditions can be attained: vertical migration of cells from low-nutrient surface waters to high-nutrient deep waters, and the introduction of low-salinity, highnutrient waters from terrestrial runoff and riverine inputs (Margalef et al. 1979, Cullen et al. 2002). Since coastal regions are optically complex, more detailed chlorophyll-retrieval algorithms are required; variability in the concentrations of coloured dissolved organic matter and non-algal particulate material limits the applicability of open-ocean algorithms.

The second turbulence-nutrient regime is highturbulence and low-nutrient conditions, associated with high-latitude, high-nitrate, low-chlorophyll (HNLC) regions (Cullen et al. 2002). The mechanisms responsible for regulation of phytoplankton community structure in these regions are still debatable. In such regimes the relationship between temperature and community structure may not be as clear as those found in the oceanic regions examined in this study. Thus, additional study is required on the principal mechanisms responsible for changes in phytoplankton community structure.

It is becoming increasingly accepted that regionally specific algorithms for chlorophyll retrieval are likely to replace globally universal ones (Carder et al. 1999, Sathyendranath et al. 2001). The principal obstacle has been to find a continuous variable (ideally, one that is accessible to remote sensing) to use as the basis for definition of the regional algorithms (Platt \& Sathyendranath 1999). Carder et al. (1999) used sea-surface temperature (SST) to improve chlorophyll estimates on global scales by dividing the world ocean into biooptical domains and comparing SST with the temperature at which nitrate levels are below the limit of detection and thus favour the presence of small cells. Our results also point clearly to temperature as a viable indicator for algorithm selection for many of the regions examined in this study. The advantage of using temperature to approximate the initial estimate of chlorophyll-specific absorption, instead of chlorophyll concentration, is that it provides a value of $a^{*}(\lambda)$ that is independent of the optical signal detected by the satellite. Furthermore, our study has shown that using both temperature and chlorophyll concentration significantly improves estimates of $a^{*}(\lambda)$ for all cruises examined in this study compared to using chlorophyll alone. As additional studies on the relationship between temperature and the absorptive properties of phytoplankton are conducted within other oceanic regions, the utility of this approach will become more clear. On a cautionary note, however, the application of temperature in regional algorithms must be made with an awareness of the main factors governing the variability in the taxonomic composition of the phytoplankton assemblage, as we have seen in the example of the Arabian Sea.

We have shown that the gross community composition and therefore size structure of the autotrophic plankton, as revealed by pigment markers and flow cytometric analysis, vary in a regular way according to the temperature distribution of the upper ocean for many of the regions examined in this study. The associated changes in optical properties of the plankton are of immediate relevance to ocean bio-optics in general. The results demonstrate the potential use of seasurface temperature in improving regional algorithms of chlorophyll-retrieval (and subsequently primary production) on synoptic scales by remote sensing, tasks that are of central significance to major contemporary issues such as the ocean carbon cycle (climate change) and interannual variability in the ocean ecosystem (fisheries). Given the fundamental importance of temperature as an ocean observable, these findings will also be of broad applicability in the analysis and modelling of marine ecosystems.

Acknowledgements. H.A.B. was supported by a NSERC research grant to T.P. and a Dalhousie Graduate Scholarship. This work was carried out as part of the Canadian contribution to the Joint Global Ocean Flux Study (JGOFS). We thank E. Head, A. Longhurst, B. Irwin, J. Anning and T. Perry for help. We also thank the officers, technicans and crew of the research vessels that participated in this study.

\section{LITERATURE CITED}

Babin M, Morel A, Claustre H, Bricaud A, Kolber Z, Falkowski PJ (1996) Nitrogen- and irradiance-dependent variations of maximum quantum yield of carbon fixation in eutrophic, mesotrophic and oligotrophic marine systems. Deep-Sea Res 43:1241-1272

Bidigare RR, Ondrusek ME, Marrow JH, Kiefer DA (1990) In vivo absorption of algal pigments. In: Spinrad RW (ed) Ocean optics X. Society of Photo-Optical Instrumentation Engineers, Bellingham, WA, p 290-302 (Proc SPIE Vol 1302)

Bouman HA, Platt T, Kraay GW, Sathyendranath S, Irwin BD (2000) Bio-optical properties of the subtropical North Atlantic. I. Vertical variability. Mar Ecol Prog Ser 200:3-18

Bricaud A, Stramski D (1990) Spectral absorption coefficients of living phytoplankton and non-algal biogenous matter: a comparison between the Peru upwelling area and the Sargasso Sea. Limnol Oceanogr 35:562-582

Bricaud A, Babin M, Morel A, Claustre H (1995) Variability in 
the chlorophyll-specific absorption coefficients of natural phytoplankton: analysis and parameterization. J Geophys Res 100:13321-13332

Carder KL, Chen FR, Lee ZP, Hawes SK, Kamykowski D (1999) Semianalytic Moderate-Resolution Imaging Spectrometer algorithms for chlorophyll $a$ and absorption with bio-optical domains based on nitrate-depletion temperatures. J Geophys Res 104:5403-5421

Claustre HM (1994) The trophic status of various oceanic provinces as revealed by phytoplankton pigment signatures. Limnol Oceanogr 39:1206-1210

Cullen JJ, Franks PJS, Karl DM, Longhurst A (2002) Physical influences on marine ecosystem dynamics. In: Robinson AR, McCarthy JJ, Rothchild BJ (eds) The sea, Vol 12. John Wiley, New York, p 297-336

Cushing (1989) A difference in structure between ecosystems in strongly stratified waters and in those that are only weakly stratified. J Plankton Res 11:1-13

Duysens LNM (1956) The flattening of the absorption spectrum of suspensions as compared to that of solutions. Biochim Biophys Acta 19:1-12

Falkowski PG, LaRoche J (1991) Acclimation to spectral irradiance in algae. J Phycol 27:8-14

Fujiki T, Taguchi S (2002) Variability in chlorophyll a specific absorption coefficient in marine phytoplankton as a function of cell size and irradiance. J Plankton Res 24:859-874

Geider RJ, Platt T (1986) A mechanistic model of photoadaptation in microalgae. Mar Ecol Prog Ser 30:85-92

Goericke R (2002) Top-down control of phytoplankton biomass and community structure in the monsoon Arabian Sea. Limnol Oceanogr 47:1307-1323

Gordon HR, Morel A (1983) Remote assessment of ocean color for interpretation of satellite visible imagery. In: Barber RT, Mooers NK, Bowman MJ, Zeitzschel B (eds) Lecture notes on coastal and estuarine studies, Vol 4. SpringerVerlag, New York, p 1-114

Gran HH, Braarud T (1935) A quantitative study of the phytoplankton in the Bay of Fundy and the Gulf of Maine (including observations on hydrography, chemistry and turbidity). J Biol Board Can 1:279-467

Head EJH, Horne EPW (1993) Pigment transformation and vertical flux in an area of convergence in the North Atlantic. Deep-Sea Res II 40:329-346

Hoepffner N, Sathyendranath S (1991) Effect of pigment composition on absorption properties of phytoplankton. Mar Ecol Prog Ser 73:11-23

Hoepffner N, Sathyendranath S (1992) Bio-optical characteristics of coastal waters: absorption spectra of phytoplankton and pigment distribution in the western North Atlantic. Limnol Oceanogr 37:1660-1679

Hoepffner N, Sathyendranath S (1993) Determination of the major groups of phytoplankton pigments from the absorption spectra of total particulate matter. J Geophys Res 98: 22789-22803

Holm-Hansen O, Lorenzen CJ, Holmes JDH (1965) Fluorometric determination of chlorophyll. J Cons Int Explor Mer 30:3-15

Jeffrey SW, Vesk M (1997) Introduction to marine phytoplankton and their pigment signatures. In: Jeffrey SW, Mantoura RFC, Wright SW (eds) Phytoplankton pigments in oceanography. UNESCO, Paris, p 37-84

Karl DM (1999) A sea of change: biogeochemical variability in the North Pacific Subtropical Gyre. Ecosystems 2:181-214

Kishino M, Takahashi N, Okami N, Ichimura S (1985) Estimation of the spectral absorption coefficients of phytoplankton in the sea. Bull Mar Sci 37:634-642

Kyewalyanga MN, Platt T, Sathyendranath S, Lutz VA, Stuart
V (1998) Seasonal variations in physiological parameters of phytoplankton across the North Atlantic. J Plankton Res 20:17-42

Lazarra L, Bricaud A, Claustre H (1996) Spectral absorption and fluorescence excitation properties of phytoplanktonic populations at a mesotrophic and oligotrophic site in the tropical North Atlantic (EUMELI program). Deep-Sea Res 43:1215-1240

Legendre L, LeFevre J (1989) Hydrodynamical singularities as controls of recycled versus export production in the oceans. In: Berger WH, Smetacek VS, Wefer G (eds) Productivity in the ocean: present and past. John Wiley \& Sons, Chichester, p 44-63

Li WKW (1995) Composition of ultraphytoplankton in the central North Atlantic. Mar Ecol Prog Ser 122:1-8

Li WKW (2002) Macroecological patterns of phytoplankton in the northwestern North Atlantic Ocean. Nature 419: $154-157$

Li WKW, Harrison WG (2001) Chlorophyll, bacteria and picophytoplankton in ecological provinces of the North Atlantic. Deep-Sea Res II 48:2271-2293

Longhurst A (1998) Ecological geography of the sea. Academic Press, San Diego

Lutz VA, Sathyendranath S, Head EJH (1996) Absorption coefficient of phytoplankton: regional variations in the North Atlantic. Mar Ecol Prog Ser 135:197-213

Mackey MD, Mackey DJ, Higgens HW, Wright SW (1996) CHEMTAX - a program for estimating class abundances from chemical markers: application to HPLC measurements of phytoplankton. Mar Ecol Prog Ser 144:265-283

Margalef R (1978) Life-forms of phytoplankton as survival alternatives in an unstable environment. Oceanol Acta 1: 493-509

Margalef R, Estrada M, Blasco D (1979) Functional morphology of organisms involved in red tides, as adapted to decaying turbulence. In: Taylor DT, Seliger $\mathrm{HH}$ (eds) Toxic dinoflagellate blooms. Elsevier/North Holland, New York, p 89-94

Mitchell BG, Kiefer DA (1988) Chlorophyll a specific absorption and fluorescence excitation spectra for light-limited phytoplankton. Deep-Sea Res 35:639-663

Moore LR, Georicke R, Chisholm SW (1995) Comparative physiology of Synechococcus and Prochlorococcus: influence of light and temperature on growth, pigments, fluorescence and absorptive properties. Mar Ecol Prog Ser 116:259-275

Morel A (1997) Consequences of a Synechococcus bloom upon the optical properties of oceanic (case 1) waters. Limnol Oceanogr 42:1746-1754

Morel A, Bricaud A (1981) Theoretical results concerning light absorption in a discrete medium, and application to specific absorption of phytoplankton. Deep-Sea Res 28: 1375-1393

Morel A, Prieur L (1977) Analysis of variations in ocean color. Limnol Oceanogr 22:709-722

O'Reilly JE, Maritorena S, Siegel D, O'Brien MC and 18 others (2000) Ocean color chlorophyll a algorithms for SeaWiFS, OC2, and OC4: version 4. In: Hooker SB, Firestone ER (eds) SeaWiFS Postlaunch Tech Rep Ser, Vol 11. SeaWiFS postlaunch calibration and validation analyses, Part 3 . NASA, Goddard Space Flight Center, Greenbelt, MD, p 9-23

Platt T, Sathyendranath S (1999) Spatial structure of pelagic ecosystem processes in the global ocean. Ecosystems 2: 384-394

Prieur L, Sathyendranath S (1981) An optical classification of coastal and oceanic waters based on the specific spectral 
absorption curves of phytoplankton pigments, dissolved organic matter, and other particulate materials. Limnol Oceanogr 26:671-689

Rodriguez J, Tintore J, Allen JT, Blanco JM and 6 others (2001) Mesoscale vertical motion and the size structure of phytoplankton in the ocean. Nature 410:360-363

Sathyendranath S, Platt T (1988) The spectral irradiance field at the surface and in the interior of the ocean: a model for applications in oceanography and remote sensing. J Geophys Res 93:9270-9280

Sathyendranath S, Lazarra L, Prieur L (1987) Variations in the spectral values of specific absorption of phytoplankton. Limnol Oceanogr 32:403-415

Sathyendranath S, Platt T, Horne EPW, Harrison WG, Ulloa O, Outerbridge R, Hoepffner N (1991) Estimation of new production in the ocean by compound remote sensing. Nature 353:129-133

Sathyendranath S, Stuart V, Irwin BD, Maass H, Savidge G, Gilpin L, Platt T (1999) Seasonal variations in bio-optical properties of phytoplankton in the Arabian Sea. Deep-Sea Res 46:633-653

Sathyendranath S, Cota G, Stuart V, Maass H, Platt T (2001)

Editorial responsibility: Otto Kinne (Editor),

Oldendorf/Luhe, Germany
Remote sensing of phytoplankton: pigments-a comparison of empirical and theoretical approaches. Int J Remote Sens 22:249-273

Sosik HM, Mitchell BG (1991) Absorption, fluorescence, and quantum yield for growth in nitrogen-limited Dunaliella tertiolecta. Limnol Oceanogr 36:910-921

Sosik HM, Mitchell BG (1994) Effects of temperature on growth, light absorption, and quantum yield in Dunaliella tertiolecta (Chlorophyceae). J Phycol 30:833-840

Sosik HM, Mitchell BG (1995) Light absorption by phytoplankton, photosynthetic pigments and detritus in the California Current System. Deep-Sea Res 42:1717-1748

Stramski D, Sciandra A, Claustre H (2002) Effects of temperature, nitrogen, and light limitation on the optical properties of the marine diatom Thalassiosira pseudonana. Limnol Oceanogr 47:392-403

Stuart V, Sathyendranath S, Platt T, Maass H, Irwin BD (1998) Pigments and species composition of natural phytoplankton populations: effect on the absorption spectra. J Plankton Res 20:187-217

Yentsch CS, Phinney, DA (1989) A bridge between ocean optics and microbial ecology. Limnol Oceanogr 34:1694-1705

Submitted: July 15, 2002; Accepted: April 9, 2003

Proofs received from author(s): July 29, 2003 